\title{
«En velfortjent Udbredning»- introduksjon av fleksible katetre til Norge
}

Katetre er beskrevet flere steder i de hippokratiske skrifter. De ble helt sikkert brukt i romerriket man har funnet flere under utgravninger i Pompeii. De tidlige typene var stive metallkatetre, men fra 1500-tallet og fremover ble det gjort stadig nye forsøk på å gjøre dem mer fleksible. Naturgummi var uegnet, siden den er for myk ved kroppstemperatur og for hard ved lavere temperaturer. Fra 1844 begynte man å behandle naturgummi med bly. Dette gjorde materialet langt mer stabilt ved skiftende temperaturer, og i annen halvdel av 1800-tallet ble det produsert en rekke katetre av slik vulkanisert gummi. Det mest berømte ble utformet av Auguste Nélaton (1807-73) i 1860. Nélaton arbeidet ved Hôpital St. Louis i Paris. Han ble professor i kirurgi i 1851 og var Napoleon IIls livlege fra 1867.

Gradvis erstattet disse fleksible katetrene de stive av metall, og ved slutten av 1800-tallet var gummikatetrene enerådende. Nélaton-kateteret anvendes fremdeles i stor skala - det er det rette gummikateteret med ett enkelt sidehull $i$ tuppen. Teksten nedenfor er fra den tiden det fremdeles var helt nytt i Norge (Tidsskrift for Praktisk Medicin 1881; 1: 12-13).

\section{Om Nélatons Catheter}

\author{
Ved reservelæge P. Voss
}

Der er I den senere Tid kommet i Brug et Instrument, inventeret i Frankrige og der kaldt "sonde souple», andetsteds kjendt under Navn af Nélatons Catheter, der hurtigt har faaet en velfortjent Udbredning. Det dannes af et blødt Rør af rød Kautchuk ligesom Drainrør og er lukket i den ene Ende og ligesom en almindelig Catheter forsynet med Fenester paa Siden nær den lukkede Ende. Den kan faaes i alle Tykkelser. Selv en fuldstændig uøvet Haand kan med dette Instrument ikke gjøre Skade i en Uretra; det frembringer ogsaa mindre Irritation, selv ved at lades længe liggende, end nogen anden slags Catheter. Man tør med dette Instrument forsøge Cathetrisation gjennem en dilacerereret Urethra (f.ex. ved traumatisk Ruptur). Det egner sig særdeles i mange Tilfælde af Prostatahypertrofi, hvor man kun vanskelig kan komme ind med sine Instrumenter, og det kan trygt overlades til indførelse af Patienten selv, som hellerikke vil have saa vanskelig for at lære Brugen af dette som af et stivt Instrument; den bløde Catheter smyger umærkelig ind i Blæren og kan paa Grund af sin Bøielighed let omgaa Hindringen i Blæreindgangen. [...]

Ved Brugen af disse Cathetre maa man erindre ikke at smøre dem med Olie eller Fedt, da de derved hurtigt opblødes og tilsidst bliver fuldstændig opløste; man bør derimod før indførelsen dryppe dem i Glycerin. For at styrke Catheteren og ikke risikere, at muligvis et Stykke skulde rives af og blive liggende i Blæren, er der gjort Forsøg med at indstøbe en Traad i Catheterens Væg fra ende til anden; saadanne Cathetre have været averterede fra Tydskland. 